\title{
Classification of Sorghum bicolor (L.) Moench Seed Vigor by Respiratory Activity
}

\author{
Erivanessa C. Sousa ${ }^{1}$, Moadir S. Leite ${ }^{1}$, Salvador B. Torres ${ }^{1}$, Fernando S. Oliveira ${ }^{1}$, Alek S. Dutra ${ }^{2}$, \\ Washington A. L. Brito ${ }^{1}$, Brenna R. V. Santos ${ }^{1} \&$ Paulo C. S. Santos ${ }^{1}$ \\ ${ }^{1}$ Department of Plant Production, Federal Rural University of Semi-arid, Mossoró, Brazil \\ ${ }^{2}$ Federal University of Ceara, Fortaleza, Brazil \\ Correspondence: Erivanessa C. Sousa, Department of Plant Production, Federal Rural University of Semi-arid, \\ Mossoró, Rio Grande do Norte, Brazil. Tel: 55-084-981-905-338. E-mail: vanessac.sousa@hotmail.com
}

Received: June 13, $2018 \quad$ Accepted: July 18, $2018 \quad$ Online Published: September 15, 2018

doi:10.5539/jas.v10n10p343 URL: https://doi.org/10.5539/jas.v10n10p343

\begin{abstract}
Seeds are one of the main inputs used in agriculture, and their quality is directly related to the success of the field crop. Thus, seed companies increasingly need to obtain fast and reliable seed quality results, making it easier to make decisions regarding the use of seed batches. In this sense, the objective was to evaluate the $\mathrm{CO}_{2}$ measurement efficiency in the classification of S. bicolor seed vigor. For this, six batches of cv. Ponta Negra seeds were used, from different national producers. The physiological quality of the seeds was evaluated by means of the following tests: germination, first germination count, germination speed index, accelerated aging, total dry matter of seedlings, electrical conductivity and respiratory activity. The experimental design was completely randomized, with four replications. The Pearson correlation coefficient between the respiratory activity and the germination and vigor tests was determined. The respiratory activity test on S. bicolor seeds was shown to be promising for the identification of differences in vigor between seed batches.
\end{abstract}

Keywords: measurement of $\mathrm{CO}_{2}$, Pettenkofer method, poaceae, physiological quality

\section{Introduction}

Sorghum bicolor (L.) Moench is an important cereal for tropical and subtropical regions in the world, being an important component of animal feeding, being an alternative to the substitution of maize, mainly in regions of semiarid climates, where this forage has been more exploited, due to the greater resistance to summer and the higher production by area (Andrade, Machado, Vilela, Camêlo, \& Silva, 2011).

In Brazil, the production of sorghum grains has increased considerably in the recent years, due to the increase of the planted area and the use of new cultivation techniques (Terra et al., 2010). However, some factors still limit the expansion of this crop, such as the difficulty of obtaining high quality seeds.

The germination test is the most used for determining the physiological quality of seed batches. However, this is not always related to the result in the field, but it can be delayed, resulting in the need to develop rapid tests that are related to the emergency in the field (Baalbaki, Elias, Marcos-Filho, \& Mcdonald, 2009).

Some traditional vigor tests have been studied and adapted for $S$. bicolor seeds, such as electrical conductivity and accelerated aging tests (Vazquez, Bertolin, \& Spegiorin, 2011). Marcos-Filho (2015) points out that the use of only one vigor test can generate incomplete information, so the usual tendency is to combine tests to obtain more accurate information.

Several vigor tests have been developed to accurately evaluate and correlate the behavior of seed batches in the laboratory (Torres et al., 2016). Among these tests, the measurement of the respiratory activity of the seeds through the Pettenkofer method comes up as an alternative to the traditional vigor tests, showing high relation with the physiological quality of the seeds (P. Marini, C. L. Moraes, N. Marini, D. M. Moraes, \& Amarante, 2012).

The respiratory activity has presented promising results in the classification of vigor of seeds of several cultivated species. This method consists of measuring the amount of $\mathrm{CO}_{2}$ released by the seeds in the breathing process, which is associated with seed vigor. It is an economic test, fast and easy to perform, according to Dode, 
Meneghello, Moraes, and Peske (2012) in Helianthus annuus; Aumonde et al. (2012) in Vigna unguiculata; Martins et al. (2014) in Phaseolus vulgaris; Venske et al. (2014) in Gossypium hirsutum; Dode, Meneghello, Timm, Moraes, and Peske (2013), and Martins et al. (2014) in Gliycine max. However, in literature, information regarding the use of this test to determine the vigor of sorghum seeds is still non-existent.

In face of that situation, the objective of this study was to verify the efficiency of $\mathrm{CO}_{2}$ measurement by means of the Pettenkofer method in the classification of seed batches vigor of $S$. bicolor.

\section{Material and Methods}

\subsection{Local and Execution Period}

The work was conducted in the Seed Analysis Laboratory (SAL) of the Agricultural Sciences Center of the Federal University of the Semi-arid Region (UFERSA), located in the municipality of Mossoró, state of Rio Grande of Norte, Brazil, in the year 2017. Six seed batches of S. bicolor, cv. Ponta-Negra were used, from different national producers. During the experiment, the seeds remained stored in a cold room $\left(10{ }^{\circ} \mathrm{C}\right.$ and $50 \%$ $\mathrm{RH})$.

\subsection{Evaluation of the Physiological Quality of Seed Batches}

Moisture content $(M C)$ : determined by the greenhouse method, at $105 \pm 3{ }^{\circ} \mathrm{C}$, for 24 hours, using two seed subsamples for each batch, and the results expressed as a percentage based on the wet weight (MARA, 2009).

Germination test $(G)$ and first germination count $(F G C)$ : performed together with four replicates of 50 seeds per batch, seeded in trays previously filled with sterilized autoclave sand, five centimeters deep and kept under constant temperature of $30^{\circ} \mathrm{C}$. The evaluations were at four and ten days after sowing, with normal seedling counts (MARA, 2009).

Germination speed index (GSI): carried out concomitantly to germination test, with daily count of germinated seedlings until the tenth day after the installation of the germination test, doing the calculations according to the formula proposed by Maguire (1962).

Seedling dry mass (SDM): after germination accounting, the normal seedlings obtained in the test were collected and packed in Kraft paper bags, being taken to the forced air circulation oven at $60{ }^{\circ} \mathrm{C}$ until they obtained constant mass, and we performed the weighing in a precision analytical balance (0.001).

Accelerated aging (AA): carried out with 250 seeds per batch, which were evenly distributed on a screen attached to the Gerbox ${ }^{\circledR}$ box with $40 \mathrm{~mL}$ of distilled water. The boxes were closed and kept in a Biochemical Oxigen Demand (B.O.D.) type germinator for a 96-hour exposure period at $41^{\circ} \mathrm{C}$ (Vazquez et al., 2011). After the period, four replications of 50 seeds per batch were submitted to the germination test, and the normal seedlings were counted on the fourth day after sowing.

Electrical conductivity $(E C)$ : four replicates of 50 seeds per batch were used, which were weighed and put to soak in plastic cups containing $75 \mathrm{~mL}$ of distilled water and kept in a B.O.D type incubator at $25^{\circ} \mathrm{C}$ for 24 hours (Vazquez et al., 2011). The imbibition water reading was performed in a conductivity meter and the results expressed in $\mu \mathrm{S} \mathrm{cm}^{-1} \mathrm{~g}^{-1}$ of seeds.

Respiratory activity (RA): the release of $\mathrm{CO}_{2}$ by the seeds was determined by Pettenkofer's method through the adaptation of the methodology described by Oliveira, Cavalheiro, Moraes, Tilmann, and Schuch (2015) for watermelon seeds, using four replicates of ten grams of $S$. bicolor seeds per batch. The seeds of the different batches were initially soaked in $50 \mathrm{ml}$ of distilled water for 60 minutes at a room temperature of $25^{\circ} \mathrm{C}$. After this period, they were placed in the Pettenkofer apparatus for another 60 minutes and the respiration was measured (Mendes, Moraes, Lima, \& Lopes, 2009). The calculation of respiratory activity was performed based equation in Müller (1964), (Equation 1).

$$
\text { Respiratory Activity }=\mathrm{N} \times \mathrm{D} \times 22
$$

Where, $\mathrm{N}=$ normality of the acid used $(0.1 \mathrm{~N} \mathrm{HCl}) ; \mathrm{D}=$ difference between the volume of $\mathrm{HCl}$ spent in the blank titration and the volume of $\mathrm{HCl}$ spent in the titration of the sample; $22=\mathrm{CO}_{2}$ normality, the result being expressed as the amount of carbon dioxide released per gram of seed, per hour $\left(\mu \mathrm{g} \mathrm{CO}_{2} \mathrm{~g}^{-1}\right.$ seed $\left.\mathrm{h}^{-1}\right)$.

\subsection{Statistical Analysis}

The experiment was conducted in a completely randomised design, with four replicates. The data were submitted to ANOVA and the averages were compared by the Scott-Knott's test $(\mathrm{P} \leq 0.05)$ of probability in the ASSISTAT program (Silva \& Azevedo, 2016). Pearson's simple correlation $(\mathrm{P} \leq 0.05)$ was performed between the traditional vigor tests and the respiratory activity of the seeds. The interpretation of the correlation was performed according 
to criterion Figueiredo-Filho and Silva-Júnior (2009): $\mathrm{r}=0.10$ to 0.39 (low correlation), $\mathrm{r}=0.40$ to 0.69 (moderate correlation) and $\mathrm{r}=0.70$ to 1 (high correlation).

\section{Results and Discussion}

The water content of the seeds of the different batches of S. bicolor was similar, varying between 13 and $14 \%$ (Table 1). The uniformisation of the water content of the different batches is an essential factor for the execution and reliability of the tests, avoiding differences in the metabolic activity of the seeds, providing consistent results (Oliveira, Martins, Cruz, \& Silva, 2014; Sena, Alves, \& Medeiros, 2015).

Table 1. Moisture content (MC), germination (G), first counting (FC), accelerated aging (AA), germination speed index (GSI), seedling dry mass (SDM), electrical conductivity (EC) and respiratory activity (RA) of sorghum seed batches (Sorghum bicolor), cv. Ponta Negra

\begin{tabular}{|c|c|c|c|c|c|c|c|c|}
\hline Batches & $\mathrm{MC}$ & G & $\mathrm{FC}$ & $\mathrm{AA}$ & GSI & DSM & $\mathrm{EC}$ & RA \\
\hline & \multicolumn{5}{|c|}{----------------- \% ----------------- } & mg seedling $^{-1}$ & $\mu \mathrm{S} \mathrm{cm}^{-1} \mathrm{~g}^{-1}$ & $\mu \mathrm{g} \mathrm{CO}_{2} \mathrm{~g}^{-1}$ seed $^{-1}$ \\
\hline 1 & 13 & $65 \mathrm{~b}$ & $62 \mathrm{~b}$ & $63 \mathrm{c}$ & $15.85 \mathrm{~b}$ & $285 \mathrm{c}$ & $27.22 \mathrm{c}$ & $0.10 \mathrm{~b}$ \\
\hline 2 & 14 & $63 \mathrm{~b}$ & $61 \mathrm{~b}$ & $60 \mathrm{c}$ & $16.80 \mathrm{~b}$ & $359 \mathrm{~b}$ & $22.11 \mathrm{~d}$ & $0.12 \mathrm{~b}$ \\
\hline 3 & 14 & $53 \mathrm{c}$ & $51 \mathrm{~d}$ & $49 \mathrm{~d}$ & $13.73 \mathrm{c}$ & $239 \mathrm{c}$ & $30.24 b$ & $0.51 \mathrm{a}$ \\
\hline 4 & 14 & $58 \mathrm{c}$ & $58 \mathrm{c}$ & $67 \mathrm{~b}$ & $17.33 \mathrm{~b}$ & $224 \mathrm{c}$ & $36.00 \mathrm{a}$ & $0.54 \mathrm{a}$ \\
\hline 5 & 14 & $63 \mathrm{~b}$ & $57 \mathrm{c}$ & $71 \mathrm{~b}$ & $17.62 \mathrm{~b}$ & $409 \mathrm{a}$ & $27.97 \mathrm{c}$ & $0.11 \mathrm{~b}$ \\
\hline 6 & 14 & $72 \mathrm{a}$ & $70 \mathrm{a}$ & $77 \mathrm{a}$ & $21.87 \mathrm{a}$ & $445 \mathrm{a}$ & $28.21 \mathrm{c}$ & $0.09 \mathrm{~b}$ \\
\hline C.V. $(\%)$ & - & 7.55 & 8.75 & 6.98 & 10.64 & 12.87 & 9.70 & 42.29 \\
\hline
\end{tabular}

Note. * Averages followed by the same letter in the column do not differ by Scott-Knott's test $(\mathrm{P} \leq 0.05)$.

The germination test showed significant differences in the physiological quality of $S$. bicolor seed batches varying from 53 to $72 \%$, with batch 6 being the one with best quality, while batches 3 and 4 resulted in lower germination values. The germination test is conducted under favorable conditions of humidity, temperature and substrate, which may overestimate the physiological quality of the seeds, thus requiring complementary tests to determine the physiological quality of seed batches (Kikuti \& Marcos-Filho, 2015).

The first germination count allowed the stratification of the batches into four vigor classes, with batch 6 (class 1), batches 1 and 2 (class 2), batches 4 and 5 (class 3 ) and batch 3 (class 4), the latter being the one with worst performance. Similarly to that verified for the first count of the germination test, the germination speed index classified batch 6 as being of greater vigor and batch 3 as of lower vigor among all. Migliorini et al. (2017) point out that for the GSI, the higher the value obtained, the greater the germination speed, and fewer days are required for the formation and establishment of the seedlings, thus evidencing a better quality of these seeds.

For the accelerated aging test, the batches were separated into four vigor classes, batch 6 (class 1), batches 4 and 5 (class 2), batches 1 and 2 (class 3 ) and batch 3 (class 4). This result confirms those already obtained in the other tests, in which batch number 6 stood out from the others because it resulted in better physiological quality.

According to Kikuti and Marcos-Filho (2015), the accelerated aging test is one of the most used vigor tests to evaluate seed quality, providing consistent information regarding the performance of seed batches in the field and after storage. This test artificially accelerates the rate of seed deterioration, so that less vigorous seeds, like those in batch number 3 , rapidly lose their germination capacity.

The dry mass of seedlings allowed the stratification of seed batches in high, medium and low vigor, with batches 5 and 6 of high vigor, and batches 1, 3 and 4 of low vigor. According to Dode et al. (2012), the seedlings that present a higher dry mass indicate a higher physiological quality of the seeds that originated them, therefore, are considered more vigorous, as verified for the seedlings of batches 5 and 6 .

Differently from the other tests, the electrical conductivity indicated batch 2 as of greater vigor, and batch 4 as of worse performance; the other batches were distributed in intermediate vigor classes. Low-vigor seeds present an increase in solute leaching resulting from the greater disorganization of the membranes of their cells (Marcos-Filho, 2015), directly affecting the germination and development of the seedlings.

The respiratory activity measured by the Pettenkofer method allowed the division of the batches into high (batches 1, 2, 5 and 6) and low vigor (batches 3 and 4). There was an inverse relation between respiration and 
vigor of S. bicolor seeds. The batches of low physiological quality (3 and 4) presented the highest respiratory rates, while the high quality ones $(1,2,5$ and 6$)$ had the lowest respiratory rates.

Based on this fact, Carvalho and Nakagawa (2012) affirm that tannin, present in high concentrations in seeds of S. bicolor, is one of the substances that admittedly confers impermeability of the integument to water. According to these authors, the concentration of these substances in the seeds is gradually reduced with the increase physiological age. Thus, physiologically older seeds with low vigor (batches 3 and 4) possibly absorb water faster than the physiologically younger ones.

Therefore, the respiratory rate in the first hour of imbibition of the seeds is higher than the rate of respiration of the most vigorous, in which the tannin, normally present in high concentrations, reduces the speed of water absorption and consequently respiration. Similar results were obtained by Dode et al. (2012) in Helianthus annuus; Aumonde et al. (2012) in Vigna unguiculata and Dode et al. (2013) in Gliycine max. All of these verified that, seeds of low physiological quality, present higher respiratory rates in relation to batches of high physiological quality, allowing the differentiation of vigor between seed batches.

The respiratory activity of the seeds is the result of the oxidation of organic substances in the cellular system with the release of energy and $\mathrm{CO}_{2}$. The main substrates of the respiratory process are carbohydrates such as starch and glucose, lipids, organic acids and proteins (Marenco \& Lopes, 2007). When they come in contact with water, the seeds begin the process of imbibition, increasing the respiratory activity and producing ATP. Thus, the amount of $\mathrm{CO}_{2}$ released from the seeds is directly related to the amount of organic substances stored. However, due to the presence of tannin in seeds of Sorghum bicolor, which prevents the rapid absorption of water in the seeds of high vigor, there was an inverse relationship between seed vigor and its respiratory rate.

The respiratory activity test showed a low correlation with the germination ones, germination speed index, first germination count and accelerated aging $(\mathrm{r}<0.39)$, and moderate correlation with the tests of dry mass and electrical conductivity $(0,40<\mathrm{r}<0.69)$. There was a negative correlation with germination tests, first germination count, accelerated aging, germination speed index and dry mass, indicating that the lower respiratory activity of $S$. bicolor seeds is related to their higher physiological quality. For the electrical conductivity test, the correlation is positive.

Table 2. Pearson correlation coefficients between respiratory activity and physiological quality tests of sorghum seed (Sorghum bicolor), cv. Ponta Negra

\begin{tabular}{ll}
\hline Tests & RA \\
\hline Germination & -0.3660 \\
First germination count & -0.1937 \\
Accelerated aging & -0.1783 \\
Germination speed index & -0.0877 \\
Dry mass of seedlings & -0.5175 \\
Electrical conductivity & 0.6367 \\
\hline
\end{tabular}

As for respiratory activity, higher conductivity values are related to the reduction of membrane integrity, since less vigorous seeds have less structured membranes and damaged cells, which is associated with the seed deterioration process (Oliveira, Cavalheiro, Moraes, Tilmann, \& Schuch, 2015), thus justifying the positive correlation between these two tests.

\section{Conclusion}

The respiratory activity test on S. bicolor seeds was shown to be promising in the identification of marked differences in the vigor of seed batches.

\section{References}

Andrade, A. R. S., Machado, C. B., Vilela, E. L., Camêlo, D. L., \& Silva, L. C. C. (2011). Desenvolvimento da cultura do sorgo em um Latossolo Amarelo submetido à adubação orgânica. Revista Brasileira de Tecnologia Aplicada nas Ciências Agrárias, 4(2), 137-151. https://doi.org/10.28998/rca.v12i1.1278

Aumonde, Z. T., Marini, P., Moraes, D. M., Maia, M. S., Pedó, T., Tillmann, M. A. A., \& Villela, F. A. (2012). Classificação do vigor de sementes de feijão-miúdo pela atividade respiratória. Interciência, 37(1), 55-58. Retrieved from https://www.interciencia.net/wp-content/uploads/2018/01/055-c-AUMONDE-4.pdf 
Baalbaki, R. Z., Elias, S. G., Marcos-Filho, J., \& Mcdonald, M. B. (2009). Seed vigor testing handbook (Contribution No. 32). Ithaca, NY, USA: Association of Official Seed Analysts.

Carvalho, N. M., \& Nakagawa, J. (2012). Sementes: Ciência, tecnologia e produção (5th ed., p. 409). Jaboticabal: FUNEP.

Dode, J. S., Meneghello, G. E., Moraes, D. M., \& Peske, S. T. (2012).Teste de respiração para avaliar a qualidade fisiológica de sementes de girassol. Revista Brasileira de Sementes, 34(4), 686-691. https://doi.org/10.1590/ S0101-31222012000400021

Dode, J. S., Meneghello, G. E., Timm, F. C., Moraes, D. M., \& Peske, S. T. (2013). Teste de respiração em sementes de soja para avaliação da qualidade fisiológica. Ciência Rural, 43(2), 193-198. https://doi.org/ $10.1590 / \mathrm{S} 0103-84782013000200001$

Figueiredo-Filho, D. B., \& Silva-Júnior, J. A. (2009). Desvendando os mistérios do coeficiente de correlação de Pearson (r). Revista Política Hoje, 18(1), 115-46. Retrieved from http://bibliotecadigital.tse.jus.br/xmlui/ handle/bdtse/2766

Kikuti, A. L. P., \& Marcos Filho, J. (2012). Testes de vigor em sementes de alface. Horticultura Brasileira, 30(1), 44-50. https://doi.org/10.1590/S0102-05362012000100008

Maguire, J. D. (1962). Speed of germination: aid in selection and evaluation for seedling emergence and vigor. Crop Science, 2(2), 176-177. https://doi.org/10.2135/cropsci1962.0011183X000200020033x

MARA (Ministério da Agricultura e Reforma Agrária). (2009). Regras para análises de sementes. Brasília: SNDA/DNDV/CLAV.

Marcos-Filho, J. (2015). Fisiologia de sementes de plantas cultivadas (2nd ed.). Londrina: ABRATES, 660 p.

Marenco, R. A., \& Lopes, N. F. (2007). Fisiologia vegetal: Fotossíntese, respiração, relações hídricas e nutrição mineral (2nd ed., p. 469). Viçosa: UFV.

Marini, P., Moraes, C. L., Marini, N., Moraes, D. M., \& Amarante, L. (2012). Alterações fisiológicas e bioquímicas em sementes de arroz submetidas ao estresse térmico. Revista Ciência Agronômica, 43(4), 722-730. https://doi.org/10.1590/S1806-66902012000400014

Martins, A. B. N., Marini, P., Bandeira, J. M., Borba, I. C. G., Quineper, R. R., Moraes, D. M., \& Villela, F. A. (2014). Vigor: separação de lotes de sementes pela atividade respiratória. Interciência, 39(4), $260-265$. Retrieved from https://www.interciencia.net/wp-content/uploads/2017/11/260-c-MARTINS-6.pdf

Mendes, C. R., Moraes, D. M., Lima, M. G. S., \& Lopes, N. F. (2009). Respiratory activity for the differentiation of vigor on soybean seeds batches. Revista Brasileira de Sementes, 31(2), 171-176. https://doi.org/10.1590/ S0101-31222009000200020

Migliorini, P., Lazarotto, M., Müller, J., Oruoski, P., Bovolini, M. P., Barbieri, M., ... Tunes, L. V. M. (2017). Qualidade fisiológica, sanitária e transmissão de patógenos em sementes de canola. Colloquium Agrariae, 13(3), 67-76. https://doi.org/10.5747/ca.2017.v13.n3.a175

Müller, L. E. (1964). Manual de laboratório de fisiologia vegetal (1st ed., p. 165). Turrialba: Instituto Interamericano de Ciências Agrícolas de la O.E.A.

Oliveira, L. M., Cavalheiro, V. B. D., Moraes, D. M., Tilmann, M. A. A., \& Schuch, L. O. B. (2015). Medição do $\mathrm{CO}_{2}$ como método alternativo para a diferenciação do vigor de lotes de sementes de melancia. Ciência Rural, 45(4), 606-611. https://doi.org/10.1590/0103-8478cr20130594

Oliveira, S. S. C. D., Martins, C. C., Cruz, S. J. S., \& Silva, C. J. D. (2014). Seleção de progênies de nabo-forrageiro para germinação sob altas temperaturas. Ciência Rural, 44(2), 217-222. https://doi.org/ 10.1590/S0103-84782014000200004

Sena, D. V. A., Alves, E. U., \& Medeiros, D. S. (2015). Vigor de sementes de milho cv. 'Sertanejo' por testes baseados no desempenho de plântulas. Ciência Rural, 45(11), 1910-1916. https://doi.org/10.1590/ $0103-8478$ cr20120751

Silva, F. A. S., \& Azevedo, C. A. V. (2016). The Assistat Software Version 7.7 and its use in the analysis of experimental data. African Journal Agricultural Research, 11(39), 3733-3740. https://oi.org/10.5897/ AJAR2016.11522

Terra, T. G. R., Leal, T. C. A. B., Siebeneichler, S. C., Castro, D. V., Dias Neto, J. J., \& Dos Anjos, L. M. (2010). Desenvolvimento e produtividade de sorgo em função de diferentes densidades de plantas. Bioscience 
Journal, 26(2), 208-215. Retrieved from http://www.seer.ufu.br/index.php/biosciencejournal/article/view/ $7065 / 4681$

Torres, S. B., Balbino, D. A. D., Santos, W. G. N., Nogueira, N. W., Freitas, R. M. O., \& Leite, M. S. (2016). Avaliação do vigor de sementes de rúcula pela atividade respiratória. Horticultura Brasileira, 34(4), 561-564. https://doi.org/10.1590/S0102-053620160416

Vazquez, G. H., Bertolin, D. C., \& Spegiorin, C. N. (2011). Testes de envelhecimento acelerado e de condutividade elétrica para avaliar a qualidade fisiológica de sementes de sorgo (Sorghum bicolor (L.) Moench). Revista Brasileira de Biociência, 9(1), 18-24. Retrieved from http://www.ufrgs.br/seerbio/ojs/ index.php/rbb/article/view/1504

Venske, E., Abreu Júnior, J. S., Sousa, A. M., Martins, L. F., \& Moraes, D. M. (2014). Atividade respiratória como teste de vigor em sementes de algodão. Revista Brasileira de Ciências Agrárias, 9(2), 174-179. https://doi.org/10.5039/agraria.v9i2a3518

\section{Copyrights}

Copyright for this article is retained by the author (s), with first publication rights granted to the journal.

This is an open-access article distributed under the terms and conditions of the Creative Commons Attribution license (http://creativecommons.org/licenses/by/4.0/). 